\title{
Engaged African Refugee Youth Negotiating Schooling in America: An Inquiry into the Influence of Culture and Social Structure
}

\author{
Vincent M Mugisha ${ }^{1, *}$ \\ ${ }^{1}$ College of Education and Social Services, University of Vermont, USA \\ *Correspondence: College of Education and Social Services, University of Vermont, USA. \\ E-mail: vincent.mugisha@gmail.com
}

Received: December 18, 2014 Accepted: February 9, 2015 Published: February 26, 2015

doi:10.5296/ije.v7i1.6807ＵRL: http://dx.doi.org/10.5296/ije.v7i1.6807

\begin{abstract}
This article explores how six ethnically diverse African refugee youth transcended constraining social structural forces and maintained high levels of academic engagement at a high school in a small Northeastern city. Using ethnographically contextualized case study methodology, this article examines the refugee youths' processes of acculturation and adaptation to American schooling. The article particularly examines the role of pre-resettlement social circumstances in refugee camps, home cultural influences, and parental scholastic expectations in shaping the participants' scholastic engagement. The findings suggest that the participants' resilience and optimism about the promise of American schooling in tandem with local community-wide support produced agency with which they transcended countervailing forces in schooling. This phenomenon is conceptualized in this article as agentic scholastic engagement.
\end{abstract}

Keywords: refugee youth, agency, culture, scholastic engagement, social structure 


\section{Introduction and Purpose of the Inquiry}

The phenomenon of scholastic disengagement among refugee/immigrant students continues to be a daunting challenge to instructional leaders and educational policy makers in the U.S. (DeCapua, Smathers, \& Tang, 2007; McBrien, 2003, 2005). Student engagement (i.e., the academically oriented purposeful actions of students in general) was found to be strongly predictive of academic achievement as measured by school-based assessments (Fredricks, Blumenfeld, \& Paris, 2004; Lee \& Shute, 2009). In line with this disengagement phenomenon, a longitudinal study by Portes and Rumbaut (2001) on children of immigrants and refugees found an average of $3 \%-10 \%$ school attrition rate. The same study found a $14 \%-25 \%$ inactive rate, i.e., the rate including students who simply stopped going to school without officially dropping out as well as those who may have moved to another district without following official transfer procedures (McBrien, 2005; Portes \& Rumbaut). Additionally, many refugee students and their families have resettled in the US with traumatic experiences, which when combined with acculturative stress and various social structural constraints, contributes to their persistent scholastic failure (Hones, 2002; Kirova, 2001; Pryor, 2001; Rong \& Preissle, 1998; Zhou, 2001).

Existing research on scholastic engagement of refugee students has focused largely on different Asian refugee groups (Blakely, 1983; Chhuon \& Hudley, 2010; Lee, 2001, 2002; Pryor, 2001; Trueba, Jacobs, \& Kirton, 1990; Zhou, 2001). This may be warranted given that Asian refugee ethnic groups represent 57\% of all refugee arrivals between 2003 and 2012 according to figures published by the U.S. Office of Immigration Statistics (OIS, 2012). On the other hand, a dearth of scholarship exists to contextualize the schooling successes and challenges of children from African refugee ethnic groups who represent $27 \%$ of all refugee arrivals in the U.S. between 2003 and 2012 (OIS, 2012). Furthermore, extant research on African refugee students' schooling in the U.S. has focused largely on the experiences of Somali refugee youth (Bigelow, 2009; Kruizenga, 2010; Roxas \& Roy, 2012; Roy \& Roxas, 2011), thereby leaving the experiences of other African refugee ethnic groups relatively unrepresented. The focus on Somali refugee students may be warranted by the fact that Somali ethnicities are the largest refugee group of African descent in U.S. However, in the last decade, numbers of other ethnic groups such as Burundians, Congolese, and Eritreans have grown by leaps and bounds (OIS, 2012).

The purpose of this inquiry, therefore, was to describe, analyze, and theorize about how a sample of African refugee high school youth representing various ethnic backgrounds transcended cultural and structural constraints and remained academically engaged. The two central research questions in this article include: 1) In what ways did cultural and social structural phenomena shape the scholastic engagement of a sample of African refugee youth at a U.S. high school? and, 2) How did these African refugee youth transcend constraining cultural and social structural influences on their schooling? 


\section{Conceptual and Social Context of Refugee Students' Schooling}

\subsection{Concept of Refugee}

In the context of this inquiry, a refugee is defined according to the guidelines in the U.S. Immigration and Nationality Act (INA) as "a person who is unable or unwilling to return to his or her country of nationality because of persecution or a well-founded fear of persecution on account of race, religion, nationality, membership in a particular social group, or political opinion” (Martin \& Yankay, 2012, p. 1). It is important to note here that the words refugee and immigrant have often been used interchangeably yet there is a meaningful distinction between these two terms that is worth educators' attention. Although Ogbu's (1982; 1987; 1999) research on immigrant students' performance has received considerable criticism (Foster, 2004), his typology of voluntary immigrants (i.e., those who chose to resettle to the U.S. for personal reasons); semi-voluntary immigrants (i.e., those described in the INA refugee definition); and the involuntary immigrants forced into the US through colonialism (i.e., slaves) enhances the justification of a focus semi-voluntary immigrants especially those from Sub-Saharan Africa. As I stated above, the schooling experiences of semi-voluntary immigrants (refugees) especially from Africa are relatively understudied, and yet refugee student numbers in the U.S. are growing unabated as evidenced in the next section.

\subsection{Patterns of African Refugee Resettlement in the U.S.}

According to the 2012 Yearbook of Immigration Statistics (OIS, 2012), 2.6 million refugees were resettled in the U.S. between 1980 and 2012 and over half a million refugees were resettled between 2003-2012 (57\% Asian and 27\% African). The total number of African refugees resettled between 2003 and 2012 was 145,456. Of this total, 43\% represented two Somali ethnic groups (the Somali and Somali Bantu), while 9\% were from Sudan. Additionally, Burundi, the Democratic Republic of Congo (DRC), Ethiopia, and Eritrea each contributed 7\%, and Sierra Leone contributed 3\%. Unlike early refugee groups of all origins that were resettled in traditionally established immigrant gateways (i.e., large metropolitan areas of California, Florida, Michigan, New York Pennsylvania, and Texas), in the last decade refugee groups have also been resettled in moderately sized towns (Martin \& Yankay, 2012; Singer \& Wilson, 2006). These alternative destinations include smaller cities in the Midwest (e.g., Des Moines, IA) and the Northeast (e.g., Utica, NY, Springfield, MA, and Portland, ME) where refugees now dominate overall foreign-born populations thereby having an impact on community efforts to enhance acculturation and social integration (Singer \& Wilson).

\subsection{Explaining Scholastic Challenges of Racial Minority Refugee Youth}

To elucidate refugees' and immigrants' educational and occupational attainment, researchers have closely studied their acculturation patterns in the U.S. At the individual level, acculturation refers to the changes in an individual's identity, values, and beliefs (Berry, Poortinga, Segall, \& Dasan, 2002; McBrien, 2005). At the social group level, McBrien suggested that acculturation happens when changes in the group's social structure (e.g., changes in their family structures or general socio-economic status) occur. According to McBrien, a related term, assimilation, is commonly understood as a process by which 
individuals consciously or subconsciously give up aspects of their old culture.

Portes (1995) developed an assimilation model named segmented assimilation and posited three possible assimilation segments in the U.S. Portes named the first segment successful upward assimilation. This refers to the straight-line assimilation of early 20th century European immigrants who easily blended into American society arguably because of their dominant racial identity. He named the second and third types unsuccessful downward assimilation into the poverty of inner-city underclasses of many racial minorities, and successful upward assimilation with conscious biculturalism.

As most refugee arrivals from sub-Saharan Africa fall into the acute refugee category (i.e., the financially poor that fled acute violence and settled in refugee camps) as opposed to the anticipatory refugee category (i.e., those with resources that are often able to plan their flight), many have been associated with unsuccessful downward assimilation in the US (McBrien, 2005). Portes (1995) explained this phenomenon by arguing that poor refugee/immigrant families were incorporated upon their arrival into urban concentrations of socio-economically and intellectually marginalized native-born racial minorities. This exposed refugee/immigrant youth to the subcultures that are developed by marginalized youth in the host community to cope with their difficult situations (Rong \& Brown, 2001, 2002). Among many characteristics, these subcultures have been associated with identities that oppose the institutional inequities in the schooling structure, thereby discounting schooling as a means of upward social mobility (Fordham \& Ogbu, 1986; Ogbu, 1982). Therefore, it is argued that when refugee youth from racial minority groups such as African refugees assimilate to inner-city underclass subcultures, they may grow to resent and disengage from schooling (Portes, 1995; Portes \& Rumbaut, 2001).

A related institutional barrier to the scholastic engagement of African refugee youth is the observation that many Americans tend to hold a monolithic view of the Black community in the US, yet different Black people have different social histories and ethnic cultures that would explain why various Black ethnic groups might engage differently with American social institutions such as schooling (Rong \& Brown, 2001, 2002). For instance, the notion of filial respect and obedience (i.e., the cultural expectation for children to obey and show deference to parents and elders or other people in authority) is deeply ingrained in many sub-Saharan African ethnic cultures (Lassiter, 2000). This implies that unassimilated African refugee youth may draw on their cultural values and engage alternatively with the institutional structures of schooling and school authorities such as teachers.

It is for this reason the successful upward assimilation with conscious biculturalism model (Portes \& Rumbaut, 2001) also referred to as the selective acculturation model (Waters, Tran, Kasinitz, \& Mollenkopf, 2010) may be viewed as a promising assimilation model for African refugee families in the U.S. Portes and Rumbaut suggested that upward assimilation with biculturalism happens when both parents and children gradually learn American cultural values and practices while remaining partly anchored in their ethnic culture and community. This assimilation model is characterized by "preservation of parental authority, little or no intergenerational conflict and fluent bilingualism among children” (Portes \& Rumbaut, p. 52). 
Refugee parents, according to this model, are able to share with their children important resources such as psychological capital (i.e., working in a consonant fashion to respond to the emotional stress associated with racial discrimination); social capital (i.e., drawing on the support of the local refugee community); and cultural capital (i.e., emphasis of useful ethnic cultural values) (Rong \& Brown, 2001, 2002). These theories have generally framed the scholarship on the scholastic engagement phenomenon of racial minority refugee and immigrant youth in the U.S.

\subsection{Specific Scholastic Challenges and Coping Strategies of African Refugee Youth}

Rong and Brown (2001, 2002) observed that Black refugee/immigrant students often face a triple disadvantage of being Black, having had limited educational and literacy development opportunities for example in refugee camps (Roy \& Roxas, 2011), and being poor in the U.S. By being Black, they are subject to the persistent institutional racism in the American education system (Bigelow, 2009; Roy \& Roxas,), and by being poor they may not be able to reap the educational benefits of living in a neighborhood with an adequately resourced school (Rong \& Brown, 2002).

Furthermore, many African refugee students are Muslim, e.g., Somali and Somali-Bantu youth, with religious traditions shunned by some Americans who associate Islamic beliefs with violence and terrorism (McBrien, 2003). Additionally Muslim refugee female youth cannot blend in and hide their Islamic affiliation, which requires them to wear a hijab, i.e., a head scarf and conservative clothing covering the entire body (McBrien, 2003, 2005; Roy \& Roxas, 2011). McBrien (2003) asserted that this sometimes caused rejection from many of the refugee students' peers, thereby potentially contributing to refugee youths' scholastic disengagement.

Research on schooling experiences of African refugees indicates how refugee youth and their parents arrive with a sense of optimism towards the potential advantages of American schooling (McBrien, 2005; Roy \& Roxas, 2011). However many African refugee youth may not successfully transcend the constraints in the social structure of schooling. Roxas and Roy's (2012) case study of a Somali-Bantu student's schooling experiences in the U.S. revealed that his optimistic perspective on schooling was not consistent with the perspectives of his teachers. While his teachers thought of him as a student who was unconcerned with his schooling, Roxas and Roy's study reported that the Somali-Bantu youth had developed useful strategies to help him cope with the pressures of high school. Considering his challenges with the English language, he strategized to complete his homework in the order of priority focusing on those assignments that counted the most for his grade. However, his teachers were not aware of these strategies or his home environment, which according to the researchers were both enabling and constraining to him. Eventually, the teachers mentally gave up on the student, and likewise his scholastic engagement deteriorated. When his performance dwindled, the student blamed himself, his home environment and cultural background, but not the social structural constraints in the school that needed improvement in order to better serve students of his ilk (Roxas \& Roy).

This brief review has highlighted the constraints that African refugee youth face in their 
attempt to transcend the countervailing forces within the American social structure of schooling. I contend that different African refugee students have varying abilities to navigate these socio-structural constraints. The following section presents the specific theoretical framework, which not only sheds light on how African refugee youth, as social actors, may transcend and negotiate away the socio-cultural constraints inherent in their schooling in the U.S., but also informs the theoretical perspectives that emerged from this inquiry.

\section{Theoretical Framework}

I grounded this inquiry in select social theoretical perspectives from sociology (Hayes, 1994; Rubinstein, 2001) and cultural psychology (Heine, 2011; Ratner, 2000). The key theoretical concepts in this framework include social structure, culture, and agency. Next, I define each of these concepts, and discuss their interrelationships in the literature, and conclude by explaining how they will be applied in my inquiry.

Although the notion of social structure is ubiquitous in sociological parlance, and is arguably situated at the core of sociological analysis, it continues to be diffuse and elusive so that educational practitioners may find the term esoteric and practically irrelevant. Social structure can mean systems of relations between groups (i.e. social class relations, or race and ethnic relations); systems of social and economic inequality; or any patterns of action and social life that are durable enough to withstand the inclinations of individuals (Rubinstein, 2001). Other sociologists simply conceptualized social structures as institutions that guide human actions (Gusfield; Geertz as cited in Hayes, 1994). A social structural conceptualization of significance to this inquiry is Rubinstein's view that social structures ultimately shape behavior via the costs and benefits or the level of opportunities they present to individuals. In summary, Rubinstein construes social structure as the array of important opportunities in society.

The other key concept in the framework is culture. Rubinstein (2001) claimed that in mainstream American sociology, culture referred to systems of beliefs, norms, values, attitudes, and worldviews of social groups that can be adduced to explain human conduct. Following this definition, American macro-cultural values would include individualism (i.e. self-reliance and autonomy); freedom (i.e., personal, intellectual and political rights); equality; justice; competition (i.e., success is achieved on individual achievement), and diversity (i.e., protection of and full participation of diverse groups) (Adams, 1988; Hollins, 1996 as cited in Sheets, 2005). Sheets (2005), however, argued that equitable application of American cultural values was often influenced by factors such as race, ethnicity, gender, and social class amongst others.

Regarding values in African cultures, anthropologist Lassiter (2000) argued that Africans displayed common pan-African cultural traits and patterns of adaptation in society. Lassiter synthesized scholarship from various African scholars who he argued consistently maintained that, "There have been, are, and will continue to be widespread cultural themes and patterns that are unique to sub-Saharan Africans” (p. 3). Makgoba, as cited in Lassiter, argued that 
peoples of African descent are linked by shared values such as hospitality, friendliness, the consensus and common framework-seeking principle, ubuntu, and the emphasis on community rather than on the individual. Further, Nyasani, as cited in Lassiter, specified the common cultural traits of Africans in his observation that Africans exhibited what could be described as a natural benign docility generally brought about by years of blind submission and unquestioning compliance to the mystique of higher authority. He stated that this benign natural docility was generally regarded as positive, legitimate, and virtuous, and therefore a value that people in positions of authority expected from subordinates.

Unlike classical sociologists who dichotomized social structure and culture as contrasting concepts (Marx, as cited in Rubinstein, 2001), several scholars in sociology observed that culture, like social structure, is a social, durable and layered pattern of cognitive and normative systems that are embedded in behavior, internalized in personalities, and externalized in institutions (Geertz, 1973; Wuthnow, 1987 as cited in Hayes, 1994). In the same vein, Hayes took a synthetic perspective on structure and culture when she observed, like social structure or relational systems, "Cultural systems not only constrain us to think and behave in certain ways, they simultaneously provide us with a range of ways to think and behave at the same time they make human thought and action possible” (p. 69). An important point in Hayes' argument here is that social structure (whether it includes culture or not) does not only constrain human action, but it also enables it. Therefore Hayes' synthetic conception of social structure as including culture discounts a structuralist/culturalist-determinist view of human action, where humans are viewed as incapable of successfully negotiating their way through, or positively and opportunistically shaping constraining social circumstances in which they find themselves. This alludes to another ostensibly esoteric and diffuse sociological concept of agency, which warrants elucidation in this inquiry.

Agency, in plain terms, refers to the intentional capacity of an actor or a human being in general, or an agent to act upon social circumstances in the world (Ratner, 2000). Hayes (1994) observed, “Agency explains the creation, recreation, and transformation of social structures” (p. 62). Hayes does not just stop at this purely optimistic conception of agency. She further argues that agency is made possible by the enabling features within, and at the same may be hindered by constraining forces of social structures. In this regard, Hayes argues that within social structures, there are not only constraints, but also therein lie opportunities for growth or change.

In cultural psychology, a body of knowledge concerned with how psychological and behavioral tendencies are rooted and embodied in culture (Heine, 2011), the ubiquity of the human agency concept is worth mentioning. A leading observation in this field is that people are not passive recipients of a reified entity called culture; rather they play an active role in making and remaking culture (Ratner, 2000). Additionally Ratner observed that agency makes and remakes culture "through creating personal meanings about the significance of things and through acts such as choosing particular kinds of friendships, jobs, or consumer products” (p. 413). In this respect, Ratner concurs with Rubinstein's (2001) view that agentic individuals are able to interpret culture opportunistically and act meaningfully in the face of constraining social circumstances. In other words, agentic individuals (such as the refugee 
youth in this study) can engage culture as instrumental means for achieving personal goals (Valsiner, 1998, as cited in Ratner). This view reflects the concept of cultural capital (Bourdieu, 1998), which describes the set of acquired cultural values and ideals that a student must engage in order to successfully navigate the social structures of schooling.

Another significant characteristic of agency worth mentioning is that agency itself depends on, and is shaped by social factors (Ratner, 2000). It is not fixed; rather it is a fluid phenomenon that is constructed by actors whose dispositions need constant social reinforcement. This set of dispositions referred to as habitus (Bourdieu, 1986, 1998) are an important consideration in understanding agency as they shape the actor's intentional actions upon social circumstances. In other words habitus shapes agency, which in turn is shaped by the socio-cultural environment in which the actor is situated.

In this inquiry I purposefully take a synthetic theoretical approach (as opposed to a dialectical one) to analyze culture as both a social structure in its own right due to its constraining and enabling characteristics, and also as an integral part of social structure. The African refugee youth are the actors whose actions (scholastic engagement) are shaped (i.e., both enabled and constrained) by various cultural-structural phenomena. The participants' African cultures, their pre-resettlement social circumstances and structural relations in Africa, their modes and patterns of acculturation in the U.S., and their different levels of agency are all expected to shape their scholastic engagement. These African youth would be expected to use their agency at different levels to negotiate their way through schooling.

\section{Methodology}

\subsection{Research Method}

A qualitative design appeared most befitting for this inquiry as it enabled me to explore and gain an in-depth and contextualized understanding of the phenomenon of interest (Creswell, 2007; Patton, 2002), i.e., the scholastic engagement of African refugee youth as shaped by cultural and social structural phenomena. I specifically used the ethnographically contextualized case study method, ECCSM (Gone \& Alcántara, 2010), which enabled me to partly employ ethnographic techniques to study and interpret participants' actions in light of extant cultural knowledge. According to Gone and Alcántara, ECCSM is a form of case study inquiry, which systematically juxtaposes primary data (e.g., interview material) with existing knowledge that furnishes details of the historical and cultural context from which primary research data are expressed.

\subsection{Research Setting}

The primary participants of this study are all students at a school that I gave the pseudonym of Old Carrollton High School (OCHS). This is a public school located in a small Northeastern city, Old Carrollton (OC), which is a federally designated refugee resettlement center in a non-traditional immigrant gateway state (Singer \& Wilson, 2006). Unlike many cities with this federal designation, OC being a small city does not have established inner-city 
neighborhoods characterized by pervasive social ills such as gang activity. With a population of 1,100 students, both the principal and diversity officer reported that OCHS was one of the largest and most ethnically and racially diverse high schools in the state and that $32 \%$ of the students were of minority races, while $29.7 \%$ were non-native born racial minorities with a home language other than English.

Additionally, the school administrators reported that OCHS' racial diversity had increased primarily because of the refugee resettlement program, which had made OC city home to immigrants and refugees speaking over 35 home languages. OCHS offers English language learner (ELL) classes to students with limited English proficiency to help them acquire the necessary academic language skills to be fully integrated into mainstream classes. Furthermore, OCHS ensures refugee/immigrant parents' involvement by employing a full-time team of multilingual home-school liaisons (MLHSL) who translate and facilitate communication between parents and the school.

Although OCHS administrators verbally expressed pride in the ethnic and linguistic diversity of OCHS, and demonstrated this pride through multiple ways, including the display of flags from various countries in the cafeteria and several phrases translated into different languages, racial tension has been present in the school climate. This tension culminated in a major protest by African students in the spring of 2012 against perceived racism. Local community advocacy groups assisted the African refugee youth in organizing the protest on the OCHS campus, involved different media outlets in the publicity of the intervention, and escorted the protesters to the state capital in order to voice their concerns to policy makers. Prior to the protest, community-based groups had been pushing school district leadership to focus more on diversity and educational equity work at OCHS and other local schools.

\subsection{Participant Recruitment Procedures and Profiles}

Before recruiting participants for the study, I spent a year working, on average, one or two days a fortnight as a substitute teacher at OCHS. This strategy helped me first to get to know the setting and better plan my entry point as a researcher. Following the ethical guidelines of my university's institutional review board (IRB), I worked through two MLHSLs using Patton's (2002) criterion sampling approach to select six refugee youth (three males and three females) as my study participants. The selection criteria included having:

- Been born in Africa and lived in a refugee camp prior to resettlement in the US;

- Attended OCHS for at least three years;

- Graduated from ELL classes and been fully integrated into mainstream classes; and

- Been generally perceived by the MLHSLs as scholastically engaged (i.e., motivated, purposefully attending classes and completing homework; actively using academic support services at school, and having post-high school study intentions, etc.).

My recruitment strategy yielded a diverse purposeful sample of participants whose profiles and demographic characteristics are presented in Table 1 
Table 1. Participant Profiles and Demographic Characteristics by End of Data Collection

\begin{tabular}{|c|c|c|c|c|c|c|}
\hline Name & $\begin{array}{l}\text { Ethnicity/ } \\
\text { Gender }\end{array}$ & Age & $\begin{array}{l}\text { Grade } \\
\text { level }\end{array}$ & $\begin{array}{l}\text { Year and Age: } \\
\text { US Arrival }\end{array}$ & $\begin{array}{l}\text { Current } \\
\text { Family status }\end{array}$ & $\begin{array}{l}\text { Parent's } \\
\text { Occupation }\end{array}$ \\
\hline Jamal & $\begin{array}{l}\text { Somali } \\
\text { (Male) }\end{array}$ & 21 & 12th & 2009 (19) & $\begin{array}{l}\text { Single mother, } 8 \\
\text { children }\end{array}$ & Cleaner \\
\hline Fatou & $\begin{array}{l}\text { Somali } \\
\text { (Female) }\end{array}$ & 16 & 11th & 2004(7) & $\begin{array}{l}\text { Single mother, } 8 \\
\text { children }\end{array}$ & Cleaner \\
\hline Mobali & $\begin{array}{l}\text { Congolese } \\
\text { (Male) }\end{array}$ & 17 & 12th & $2010(14)$ & 2 parents, 9 children & Truck driver; housekeeper \\
\hline Mutoni & $\begin{array}{l}\text { (Burundi } \\
\text { (Female) }\end{array}$ & 16 & 11th & 2007(10) & $\begin{array}{l}2 \text { parents, a grandma, } 6 \\
\text { children }\end{array}$ & $\begin{array}{l}\text { Factory worker; } \\
\text { housekeeper }\end{array}$ \\
\hline Nabilah & $\begin{array}{l}\text { Somali-Bantu } \\
\text { (Female) }\end{array}$ & 16 & 11th & 2004(7) & 2 parents, 5 children & $\begin{array}{l}\text { Asbestos remover; } \\
\text { housekeeper }\end{array}$ \\
\hline Omondi & $\begin{array}{l}\text { Burundi } \\
\text { (Male) }\end{array}$ & 17 & 12th & 2008(12) & 2 parents, 10 children & $\begin{array}{l}\text { Factory worker; } \\
\text { housekeeper }\end{array}$ \\
\hline
\end{tabular}

\subsection{Researcher's Positionality}

In this inquiry I was neither completely an insider nor an outsider, but rather a partial insider as I shared one or a few identities with a considerable degree of distance or detachment from the African refugee communities in the setting (Chavez, 2008). As a reflexive researcher, I felt obliged to make explicit my social background and identity with which I came to this study. Using Ogbu's (1987) terms, I am a voluntary African immigrant who came to the U.S. for academic and professional purposes. Though privileged to be educated at American institutions of higher education, I have a humble traditional African family background with social circumstances similar to the families of the African refugee youth in the sample. My mother never went to school and is semi-literate in her native African language thanks to the work of missionaries who enrolled her in functional literacy classes so she could learn how to read religious material. My grandmother who partly raised me was completely illiterate. My father only completed six years of basic education. While he believed in his children's education, he struggled to financially support my schooling in East Africa.

Thanks to the additional support of educated and employed relatives, I was able to graduate from high school and gain access to college scholarships, which later paved my way to international education and career opportunities. For over 10 years, I have been working in service delivery to poor and marginalized social groups in various developing countries. With my social background, I continue to be motivated to work as an advocate for, and in the service of, marginalized social groups, and there is no doubt that my social background led me to this research study. However, like other researchers in my position (Dwyer \& Buckle, 2009) argued, I do not believe that being an insider of some sort necessarily made me more or less effective in this research process. Nonetheless, my partial insiderness gained me expediency of access to the participants and helped equalize my relationship with them (Chavez, 2008). 


\subsection{Data Collection Procedures}

To ensure credibility, I observed the principle of triangulation (Denzin \& Lincoln, 2000; Patton, 2002) by initially holding conversational interviews with the OCHS principal and diversity officer to get demographic information and their description of the school culture and climate. I also held an informal conversational interview with the School District ELL Services Director to gain information about central office policy trends regarding the educational concerns of refugee students at OCHS. Next, I held and audio-recorded 90-100 minute-long semi-structured in-depth interviews with each of my six primary participants, and the African refugee youth. I used Patton's interview guide approach to "ensure that the same basic lines of inquiry are pursued with each person interviewed” (p. 343). To be consistent with ECCSM techniques (Gone \& Alcántara, 2010), I used themes from extant literature on African and American cultural knowledge (Bellah, 1998; Bellah, Madsen, Sullivan, Swindler, \& Tipton, 1986; Kamya, 1997; Lassiter, 2000) to probe into participants' socio-culturally constructed experiences and engagement with American schooling.

To understand home culture and parents' dispositions about schooling, for each participant, I held two participant-observations of the relations and interactions between research participants and parents and other relatives in their homes. In participants' homes, I sometimes cooked and ate with the family and also assisted with certain activities such as moving from one house to another. I also held conversational interviews with parents about their social experiences as African parents in the US, their scholastic expectations for their children, and involvement in their children's schooling.

At OCHS, I conducted one non-obtrusive observation for each participant of a class in which there were at least a total of three African students. Following this observation, I also reviewed the participant's notebooks and classwork (Chapman, 2003) to assess the extent to which the data from students' work sample analysis corresponded to the data from interviews. I then held 30-minute semi-structured interviews with the classroom teachers to obtain their perspectives on participants' academic engagement. Since OCHS runs after-school study/homework activities, I formally observed both as a non-participant and a participant three sessions in a period of two months to monitor the persistence of the participants' use of these opportunities. The school cafeteria being an important space for students, especially black students who primarily sat at separate tables (Tatum, 1997), I joined select tables where my study participants were sitting on 10 different occasions throughout the five months of data collection. Recorded in-depth interviews and the multiple field notes were transcribed to produce the data, which were analyzed according to the procedures described in the next section.

\subsection{Data Analysis}

Heeding Coffey and Atkinson's (1996) advice that, "We should never collect data without substantial analysis going on simultaneously" (p. 2), I employed an iterative inductive data analysis approach including both informal and formal processes. Throughout the data collection, I practiced analytical memoing, i.e., I conducted preliminary syntheses of the data in the form of notes to self in order to inform the next data collection steps, and to document 
emerging ideas, concepts and their relationships with extant theory (Marshall \& Rossman, 2011). Formal analysis constituted actual coding of the data (transcripts) on individual participants and generating a list of inductively emergent codes. I then entered the initial coded themes into six separate excel charts. Next I moved around the initial themes and grouped them together to form broad emergent analytical themes. Under each broad theme, I derived and wrote an emergent general observation statement. From these broad analytical themes and general observation statements, I finally generated the following six categorical themes: (1) surviving challenging social circumstances in Africa; (2) schooling in refugee camps; (3) imagining a life in America; (4) acculturating to American schooling; (5) making sense of the cultures; and (6) engaging the social structure of American schooling.

With the six data analysis excel charts, I was able to return to the primary participants for member-checking (Merriam, 1998). With my intention to make member-checking less burdensome to the six participants, I used the detailed excel sheets to explain the process of deriving finding statements, and asked them if these findings statements accurately represented their views. As part of the member-checking process, I also held two debriefing sessions with the OCHS diversity officer to triangulate participants' views especially about the school's racial climate. The six excel data analysis charts also facilitated my effort to conduct a cross-case analysis of themes and findings about participants.

\section{Findings}

Data analysis procedures generated the aforementioned six categorical themes that I represent below in an attempt to address the central research questions.

\subsection{Surviving Challenging Social Circumstances in Africa.}

The six participants reflect what may be called a pan-African identity by virtue of their living in interethnic/intercultural settings in Eastern/Central Africa prior to their resettlement to the US. Jamal and Fatou, ethnic Somalis, were born and raised in different refugee camps in Eastern Kenya where their parents had taken refuge from protracted war in Somalia. Mobali and Omondi were both born in the Democratic Republic of Congo (DRC) of Congolese, and Burundian parents respectively, but fled the war as little children with their parents to settle in refugee camps in Tanzania. Mobali (and his older brother who acted as his guardian in the study) proudly reported on his ability to speak Swahili, French, Kibembe and a little of Kirundi and Lingala by the time he was resettled. However, Mobali reported having lost three of the languages in his acculturation process, and retained English, Swahili, and some French.

Mutoni, ethnically a Burundian, was born in a refugee camp in Tanzania where her parents had settled having fled violent ethnic conflict in Burundi. Nabilah, ethnically a Somali-Bantu, was born and lived with her parents in a refugee camp in Northern Kenya. Her parents reported that being historically oppressed ethnic minorities in Somalia; they had to flee from the protracted violent Somali ethnic conflict. The participants' social backgrounds speak to the argument that participants had already been exposed to multicultural/multilingual living, which would possibly shape their acculturation processes in the US in certain ways. 
Interviews with participants, parents, and MLHSLs suggested that social conditions in refugee camps in Kenya were harsher than in the camps in Tanzania. The three refugee camps in Kenya were all located in semi-arid regions where refugee families could not grow their own food; therefore, they largely depended on food assistance from the United Nations refugees' agency (UNHCR). To meet other material needs for their families, parents undertook different activities. Jamal's mother sold used clothes on behalf of native Kenyan retailors; Fatou's mother bought and resold vegetables and fruits in the camp and also received assistance from relatives who had been resettled in Denmark. Nabilah's mother made and sold local bread, while her father worked as a security assistant in the camp.

On the contrary, Burundian participants' parents stated that refugee camps in Tanzania were located in the Western part of the country, which was fairly well endowed with rain and fertile soils permitting refugee families to grow food to supplement assistance from the UNHCR. Omondi narrated: "Every weekend, we woke up early morning and walked about two miles away from the camp to a place where we had access to farm land. There we grew cassava, sweet potatoes, corn and beans." Mutoni's parents were involved in community organizing. Her father, being relatively educated, reported having been among the group of refugee parents that worked with the United Nations children's agency (UNICEF) to start up a school in the refugee camp. So he earned a living through teaching while the mother mobilized refugee families to enroll and maintain their children in school. To earn a living and support his family, Mobali's father bought and resold local products and also worked as a handyman in the refugee camps. This background information demonstrates that participants developed a considerable degree of resilience and capacity to transcend challenging social circumstances in the refugee camps.

\subsection{Schooling in Refugee Camps}

Separate interviews with participants, their parents, and the MLHSLs, and the review of old school records confirmed that all participants had attended schools in refugee camps, which were partly supported by UNICEF and UNCHR. Jamal, with the most years of schooling in the camps, described being in classes of 60-70 students that were taught by authoritarian teachers. He reported that students were required to be passive learners and do only what they were told to do. He learnt by memorization and was required to reproduce information exactly the way teachers had taught it in class. In the early years, Somali was the medium of instruction if the teacher was Somali, and English and Swahili were taught as second/foreign language subjects. Sometimes his teachers were Ethiopian or Kenyan and taught classes in English, which he did not know well, and he was therefore not able to learn effectively. When he came to the eighth and ninth school years, all classes were taught in English. Jamal expressed that he still enjoyed school in the camp, although he suffered hunger. His mother also confirmed Jamal's enthusiasm about schooling in the refugee camps.

Next to Jamal came Mobali in terms of the number of schooling years in the camps. From separate interviews with Mobali, his older brother (who acted as a key guardian informant) and the MLHSL for Burundian and Congolese families, I learned that Mobali experienced unstable schooling because the UNHCR moved his family three times between camps. In the 
final camp, there were no formal schooling opportunities because it was a transitional camp for those refugees awaiting repatriation or overseas resettlement. Mobali, however, benefited from non-formal English for the children program, which was meant to ease his acculturation should his family be resettled in the US.

From interviews with participants and their parents, it was evident that Mutoni and Omondi had five years of relatively effective schooling prior to resettlement. Kirundi was both their home and curricular language while French was taught as a second/foreign language. Mutoni's father, who was an elementary school teacher, reported that UNICEF provided basic school materials in most refugee camp schools. Omondi's parents reported that he used to be among the best students with strengths in science and math and hoped that God would help them get resettled in a place where he would have a better chance of schooling.

Though Fatou and Nabilah were resettled after only two years of school, they still had vivid memories of their schooling experiences in the refugee camps. Fatou started out in the public refugee camp school; however, her mother moved her away from the camp school. She stated that the focus there was more on religion than on other equally important content. Thanks to financial support from her relatives in Denmark, she enrolled Fatou in what was perceived to be a better private school right outside the camp. There Fatou reported being subject to tough discipline, which included being spanked if she was late or did not successfully memorize her lessons or if her nails were not well cut. Nabilah remembered how she spent more time playing than learning because the teachers would sometimes miss classes. In summary, the participants had varying experiences of schooling in Africa that would shape their schooling in America in different ways.

\subsection{Imagining a Life in America}

From in-depth interviews with the participants, I documented their pre-resettlement expectations and imaginations about social life in the U.S., which I considered of significance to the inquiry. When his mother broke the news about resettling to the US, Jamal expressed the following sentiment:

I was happy to leave the life of suffering in the refugee camps behind me, and come to America where I knew I would get a chance to finish high school and be the first in my family to go to college, get a job, make a good life and also help my old mother.

Mobali expressed similar expectations. He stated:

I was very happy because we had been in three different camps for 10 years suffering and sometimes not having enough to eat. We always heard that in America you can become rich, and I also knew that in America you can get to see famous people, or even become famous.

On the contrary, Omondi reacted to the news with ambivalent feelings. He and his parents stated that he was initially sad that he would be leaving his friends in the camp, but at the same time he was happy especially when his parents told him that in America there were 
many opportunities for getting educated, getting good jobs and returning to Africa as an important person. As for Mutoni, Jehovah's Witness missionaries in her refugee camp had shaped her imaginations about America. She narrated:

When I heard the news, I was excited because Jehovah's Witnesses had been distributing magazines in our camps showing White people with happy faces near tall buildings. So I thought I would also live in America like these happy people.

Although Fatou and Nabilah were relatively young, they had vivid memories about their expectations and reactions. Fatou described her ambivalent feelings: "I was actually sad because I didn't want to leave my friends and relatives behind until my mother said it is a good opportunity to get a better education than in my private school in Kenya.” Nabilah and her father reported that she reacted to the news with indifference perhaps because she never knew the meaning of America. These expectations and imaginations are worth presenting, as they would be expected to shape participant's acculturation processes and adaptation to American schooling in different ways.

\subsection{Acculturating to American Schooling}

As a 19-year old male, Jamal arrived in OC with his six siblings and mother in 2009. The local refugee resettlement program (RRP) provided his family with the standard basic assistance package for refugees, i.e., a six-month stipend, subsidized medical care, and food assistance. Full of optimism about the opportunity to advance himself through schooling, Jamal and his mother would soon be dismayed to learn that he could not attend school. Jamal expressed his discontentment:

I was disappointed when the caseworker told me that I can't go to school because I am older than 18, that I must go to work and help my single mother with rent and other expenses. I said to myself, how can they deny me the opportunity to get education in America?

To resolve this concern, Jamal and his mother negotiated with the caseworker an officially acceptable deal. The mother would work one full-time and two part-time cleaning jobs, which earned her enough money for basic household expenses. Jamal finally enrolled as a ninth grader at OCHS. However, a month later the family was advised to move to a cheaper and bigger house in Winston-Carrollton (WC), a neighboring small town which had also become racially diverse due to the refugee resettlement program. In the new city, he attended for two years Winston-Carollton High School (WCHS), a school with fewer resources that was also publicly known as one of the worst performing schools in the state.

After two years at WCHS, Jamal and his mother reported that they were granted subsidized federal housing in OC, which meant an opportunity to return to OCHS, which was publicly known as a better resourced and academically better performing school in the state. Asked to describe his early schooling experiences in the US, he narrated:

Everything at OCHS was better than my school in Kenya. We got real food for lunch, unlike the only one bowl of porridge in Kenya. The teachers were nice to 
me, and had all materials, so I had no excuse for not learning. But I am not totally dissing the school in Kenya because I learnt some English there, which helped me here, but sometimes students laughed at me. For example one time I said to the teacher before I went to the bathroom: "Excuse me Madam, can I go in the toilet?”, which was normal thing to say in Kenya, but students broke out laughing. Although I was a little offended, I never gave up on the English language.

It took Jamal three and half years to graduate from ELL classes and become fully integrated into mainstream classes. This happened in his final year at OCHS.

Mobali, who had no formal schooling for two years in his transitional camp, arrived in WC with his family of 11 members in April 2010. Soon his parents successfully negotiated with caseworkers to move to OC so that Mobali could enroll in a good school, OCHS. Finally Mobali and his four older siblings were all enrolled in ninth grade at OCHS. About his early schooling experiences, Mobali narrated:

It was enjoyable to be at a school in America. I was looking forward to be in class with American people. I felt it was better to learn English by being with Americans in class because you are forced to speak with them and that's how you learn fast. But I was in class with my siblings, and students from Somalia, Thailand, Bhutan, which is O.K. But we were not speaking English with each other, and yet I wanted to learn English quickly.

Mobali persisted in ELL classes until the end of $11^{\text {th }}$ grade, which is when he was declared adequately proficient in academic English. He finally began his $12^{\text {th }}$ grade in August 2013 fully integrated into mainstream classes.

Omondi arrived in OC with his parents and eight siblings, two of which were pregnant sisters who would soon give birth, thereby growing the family size to 12 members. With assistance from RRP, Omondi and his family initially settled in Huntsville-Carrollton (HC), a poorer section of OC. He was enrolled at Huntsville-Carrollton Middle School (HCMS) in $6^{\text {th }}$ grade. A year later, Omondi and his family moved to WC where rent was cheaper. Omondi transferred to the middle school section of WCHS. When his family finally qualified for federally subsidized housing in OC, he transferred to OCHS at the end of $9^{\text {th }}$ grade and was integrated into mainstream classes right away. Asked to describe his early schooling experiences in the US, he stated:

Everything was different. English was hard, and I could not communicate with American children and teachers. But thank God I knew basic French, which initially helped me to speak with some ELL teachers. I met a good Somali friend, who spoke Swahili and also helped explain things in English. Math was sometimes easier for me because the math I did in Africa was higher level, but sometimes I would do math badly if the teacher asked me to solve a problem in written English.

Omondi stated that what he had learned in his refugee camp school, especially in math and sciences, prepared him to make faster progress in American schools. 
Mutoni and her family of nine members settled and remained in the HC section of OC since their resettlement. She enrolled in $5^{\text {th }}$ grade and ELL classes at Huntsville Elementary School (HVES). A year later she progressed to HCMS where she completed her middle school, and then entered OCHS where she continued in ELL classes and finally began her $10^{\text {th }}$ grade fully integrated into mainstream classes. About her early school experiences in America she narrated:

Going to school in America was very tough for me because of English. I sometimes would sit in math classes with Americans who were doing the math that I knew and could do well, but I could not participate because of English. So I knew from the beginning English was the key thing for me. In $6^{\text {th }}$ grade I never talked in class because I was shy, in $7^{\text {th }}$ grade I talked a little, then in $8^{\text {th }}$ grade my English got better so I started participating in class. Finally I was so excited to join high school because I was going to be treated as a young adult, but I also heard high school was hard, so I had to get prepared to work harder.

Mutoni categorically expressed that OCHS was a better school than HVES and HCMS, and that she appreciated her class activities at OCHS.

Fatou and her family initially settled in a medium-sized city of an established Northeastern immigrant gateway state. After one year and a half, Fatou's mother explained how she was unsatisfied with the inner-city school conditions, so she moved the family to a smaller city in a non-traditional Northeastern immigrant gateway state where she found better opportunities for herself and the children. However, after five years there, Fatou's mother stated that she realized how many Somali children of her friends were getting involved in gang activities, and she therefore decided to move her children away from that environment. Through the network of her Somali friends, she had heard of OC being a smaller city with little or no juvenile criminal activity. She eventually moved her family to OC.

Fatou enrolled as a non-ELL student in $7^{\text {th }}$ grade at HCMS and remained there until she progressed to OCHS. She passionately described her initial schooling experiences in her new home city of OC as follows:

Before I joined HCMS, my Somali new friends told me certain American students were racist and treated them badly, saying things like "stinky African, go back to your country.” I didn’t believe that myself, until an American boy called me stinky African. When I transferred to OCHS, I was happy because there were all these African students from everywhere. We bonded well and we would sit together at lunch tables and have fun. We would even study together, and we still do that.

Fatou also explained how cases of blatant racism were fewer at OCHS than they were at HCMS.

Nabilah and her family arrived in OC in 2004 and remain there to date. From interviews with Nabilah and her father, the family's transition and acculturation was easier because of her father's proficiency with English. Nabilah was enrolled in $2^{\text {nd }}$ grade at HCES. Her father explained that she made quick progress with English partly thanks to his support at home. 
She progressed to OCMS still attending ELL classes until she was integrated into mainstream classes in $7^{\text {th }}$ grade, and later joined OCHS in $9^{\text {th }}$ grade as a regular non-ELL high school student. About her up-to-date American schooling experiences, she narrated calmly:

Initially when I was placed in ELL classes as a little $2^{\text {nd }}$ grade girl, I was not scared because there were many children from my culture. But sometimes I would get scared when they placed me in class with American children. When I got to OCMS learning together with American children was not scary because I already knew English well enough. When I joined OCHS in $9^{\text {th }}$ grade, things were easier because I knew many other students from my culture. But sometimes there were these American children who gave me a negative look as if they wanted to tell me I don't belong here.

The study participants described their experiences of adapting to schooling in the U.S. They expressed how their primary challenges were with the English language, which they needed to learn in order to effectively engage with schooling as African cultural beings operating within an American cultural framework.

\subsection{Making Sense of the Cultures}

Interacting with the participants' parents both as a participant-observer and a conversational interlocutor, I learned of their strong attachment to their African cultural values. They continued to push these values for their children using different strategies. The two Burundian parents sent their children to Saturday Kirundi school in the community which held various socio-cultural activities in which both Mutoni and Omondi occasionally participated. Through the OC Somali-Bantu Association, Somali-Bantu families also sent their children to frequently organized activities designed to address African socio-cultural themes and academic issues in which Nabilah participated. The Somali families, although of considerable size in OC, did not run their own ethnic association. Nonetheless, Jamal and Fatou's parents played important cultural training roles in the family. Mobali's parents, who were present during only one of the four observational visits due to inflexible work hours, entrusted the cultural training responsibility to his older siblings, one of whom was a key informant in my study.

The six participants had been living in the US where they were exposed to American culture for three or more years. They also continued to live in their African families, which enforced African cultural values and traditions. During the in-depth interviews, participants compared and contrasted their perceptions of African and American cultures and described the implications of these perceptions for their schooling. Jamal expressed the following comparative cultural perceptions:

Speaking of Somali culture, Somali people and I think Kenyans also tend to be conservative. For example girl and boys can't have sexual relations until they marry. For us children we must respect and obey our parents, and respect all adults. Adults have power over you and that is why teachers in Africa can hit you for bad manners. But in America, it's the opposite. Children have freedom to do what makes them happy. They don't have to obey adults. I have seen some 
American children shouting to teachers, and that's bad. Another different thing is that we African children have to work hard now to help our parents when old. American parents must have their own money when old.

Mobali and Omondi, like Jamal, felt African culture empowered parents to demand children's respect and obedience. They both also voiced the same perceptions of relative freedom for children in American culture, which they claimed was absent in African cultures. With a sad facial expression, Mobali stated:

We African kids can't decide things we like, not even what we want to do for future, because our parents make those decisions for us. I can’t do music and sports, which I like because I am good in them because my father wants me to do only things that will make me go to college.

Additionally Omondi and Mobali also expressed their African cultural expectations to work hard today in order to take care of their old parents in the future.

On the contrary, the female participants' perceptions differed from the males' in that the females took a more critical stance in their comparative cultural interpretations. While Mutoni expressed the same African cultural ideals of respect and obedience for adults, she also felt that gender discrimination permeated African cultural practices. Mutoni stated:

I agree with the issue of respect and obedience for parents and adults in African culture. But I don't agree with the way African parents put down girls, and make girls work more than boys. [Smiling] for example, I have a grandmother at home who I love much, but she is so traditional. For her, girls are just responsible for housework. She sees no problem when boys can relax at home or do their homework, while girls are bearing the burden of domestic work.

About American culture, Mutoni expressed how the theme of freedom is everywhere. She argued:

In American culture freedom is even in the constitution. Young people can choose to wear anything they want or study something of their passion, but in my culture, you do one little thing of your choice, and soon you hear people asking, "what kind of girl is this who doesn't obey her parents' advice?”

Fatou and Nabilah, too, expressed the same perceptions of the African cultural values of respect and obedience for adults but in more critical terms, and also suggested that these values were less pervasive in American culture. Concerning her ethnic culture Fatou stated:

It is difficult for me to accept this cultural thing that a young woman like me can't have the freedom American girls have, such as leave the house and go and hang out with fellow young people. So as a young African girl, you stay at home all the time cleaning and cooking, when your older brother is chilling out and is allowed to go and be with his friends.

Nabilah expressed a similar sentiment in her narrative below: 
In American culture, young people like me have freedom to do fun things, hang out with their friends after school and on weekends, but in my culture a girl of my age should not be going out much. You get a bad name, and you embarrass your parents if you are seen walking around a lot. So I choose to stay indoors and help with domestic work, which what most girls in my culture do anyways, except for the bad ones.

Acting as cultural connoisseurs, the participants all expressed one common theme about African cultures, the value of respect for and obedience to adults. On the other hand, the one common theme about American culture across participants' perceptions was the value of freedom, which they felt American children both enjoyed and sometimes misused. In my conversational interviews with select participants' teachers, I sought to learn if these teachers had observed any cultural values-based behaviors in the participants' classroom behaviors. Jamal and Mutoni's algebra-II teacher stated: "Jamal and Mutoni are friendly, respectful, and highly motivated. You can tell they are doing the subject on purpose to go to college." Mobali's history teacher observed, "Mobali has a great deal of respect for his teachers and fellow students. I wouldn't say many students in my classes are like him. As teachers, we appreciate students who respect fellow students and their teachers.”

Omondi's pre-calculus teacher stated: "Omondi is respectful, well adjusted, and fully integrated into the class. He is a self-advocate, and actively seeks me out for clarifications about content.” Similarly, Fatou's algebra-II teacher reported:

Fatou, like the other three African students in this class, is respectful and motivated to try hard. Also when their parents come for conferences with me, they politely thank me for educating their children. I find it interesting because rarely would American parents thank me for teaching their children. But in my other classes, I must say, there are certain African students who have developed an unusual attitude of entitlement. So they tend to act differently than Fatou.

Nabilah’s English teacher stated:

I have observed in Nabilah as well as other African students that I teach that they tend to know better than regular American students when it is time to talk, and be quiet in class. Nabilah is generally quiet, well behaved and respectful.

These teachers generally appreciated the participants' cultural values, which shaped their classroom behavior. The same cultural values would be expected to play a role in the way the participants generally engaged with the social structure of American schools to meet their personal goals.

\subsection{Engaging the Social Structure of Schooling}

According to the theoretical underpinnings of this inquiry, the social structural characteristics of schooling could include, among others, social relations (such as race/ethnic relations; home-school relations; teacher-student or student-student relations); and an array of available opportunities necessary for students' success. It is worth presenting the findings on how 
different participants engaged with these social-structural characteristics.

In-depth and conversational interviews with all participants and their respective parents/guardians indicated that participants acknowledged the availability of different opportunities at OCHS that enhanced their progress. Jamal personally appreciated and seized the opportunity to learn English in his statement that, "They give us free opportunity of ELL classes, and when we have learned enough, they put us in class with American students.” On the other hand Mobali appreciated and seized the material and academic support opportunities at OCHS:

The support we get from school like free lunches, free class materials, free bus pass, and fees for things like SAT test help us because our parents don't have enough money. Also, after-school homework help activities are free, and most students there are refugees. Without these opportunities I don't think I would be in school.

Omondi and Mutoni reflect the same notion of recognizing and seizing the available opportunities. Omondi observed: "Coming from the refugee camps with no good opportunities, I am eager to do well here. I have teachers who know how to teach, and also the opportunity to get help with homework and learn knowledge that will help me in future.”

Similarly Mutoni stated: “In Tanzania, I was not lucky to have opportunities to succeed in life. Here I have teachers giving me free good education, [smiling] free lunch although the food is not that great, the after-school homework help, why can't I use this chance to do my best?”

Fatou and Nabilah also recognized the existence of educational opportunity, but they took a critical and transformative stance in their scholastic engagement. They observed the existence of racial relations that were getting in the way of their purposeful schooling. Two of the three times when I sat as a participant-observer at lunch tables of mainly Somali and Somali-Bantu students, I overheard Fatou, Nabilah and their African friends talk about American students who made fun of their traditional garb. Furthermore, they also spoke about a school library staff member who used a less polite tone whenever she addressed them than she did to other students, especially American students. Similarly, during two of the three general unobtrusive observations I held in the cafeteria, two incidents occurred in which two Somali girls were involved in high-pitched fights. A white girl made a generalized remark: "Why are those African girls always fighting?” Soon Fatou would confirm a similar remark in my in-depth interview by stating: "Sometimes I get upset when American students say things like, you are nice, you are not like other African girls who fight a lot in the lunch room.”

Similarly, during the in-depth interviews with participants, Fatou, Mutoni and Nabilah explained how they were not impressed with the persistent low academic performance of refugee students in the state's standardized assessment tests (SSAT) that all $11^{\text {th }}$ grade students were required to take under the federal policy of No Child Left Behind (NCLB). These participants explained how they did not see the logic of making a refugee student still struggling with English take this test, which even many native English speakers frequently failed. Nabilah stated: "When in the news they announce that in the SSAT results refugee 
students continue to perform badly, then you hear Americans making fun of refugee students.” Fatou narrated how an OCHS group of African refugee students supported by former African refugee students and local advocacy groups staged an anti-racist protest on campus:

When the media released the SSAT results in Spring 2012 showing what you expected, a math teacher made an insensitive comment in the news that ELLs' scores are "statistical outliers." So we got organized and protested against racist behaviors. The news people came on campus, and we put our issues out there, and our voices were heard, and now the school people at the top are doing better to promote diversity issues.

Jamal mentioned that he was aware of the protest, but he deliberately decided not to participate because he feared that the protest could get in the way of his good relationships with his teachers and students. Mobali was aware of the protest and stated that he would have participated, but he was in a class that he did not want to miss. Mutoni and Omondi reported also being aware of the protest, but they were afraid of their parents who wanted and expected them to respect and obey school authority as a means of negotiating their way through the social structure of schooling.

All participants regardless of whether they took part in the anti-racism protest or not agreed on one outcome: the protest ushered in an improved racial climate at OCHS. Participants argued that following the well-publicized anti-racism protest, OCHS enhanced its commitment to equity of academic outcomes for refugee students. In a conversational interview I held with the central office ELL Services Director, she confirmed that following the protest, the school district had reorganized the diversity and equity office to ensure more attention was directed towards educational equity issues. In the same vein, she confirmed that a policy document constituting a strategic plan to enhance educational equity was issued in the same year.

At OCHS, according to the Diversity Officer, they accelerated implementation of a policy that was in the offing to allow at-risk students to repeat $12^{\text {th }}$ grade, thereby enabling them to refocus on post-high school college or vocational plans. During the study, Jamal was in the process of repeating $12^{\text {th }}$ grade in order to complete the courses required for college entrance, which he had not been able to complete while he was still in the ELL program. Thanks to this favorable policy, at the end of the study in December 2013, Jamal received his first four-year college acceptance with partial scholarship funding. He appeared to be on his way to realizing his dream of becoming a first-generation college entrant. In the same vein, Mobali was not sure of entering college because he was missing a few required courses such as algebra-II. He therefore was also contemplating seizing this opportunity and better positioning himself to pursue his post-high school study dreams that were also his parents' preference over sports and music. At the end of my data collection process in December 2013, the participants' academic standing and engagement appeared as follows in Table 5.1.2.

The data below reflect the scholastic outcomes of the six youth who learned how to capitalize on available opportunities and negotiate their way through the constraining aspects of schooling as African refugees in the U.S. 
Table 2. Participants’ Academic Standing by End of Data Collection

\begin{tabular}{|c|c|c|c|c|c|c|}
\hline Name & $\begin{array}{l}\text { Cumulative } \\
\text { GPA }\end{array}$ & Absences & $\begin{array}{l}\text { Best subject } \\
\text { last } 1 / 5\end{array}$ & $\begin{array}{l}\text { Grade in } \\
\text { Math-Last } \\
1 / 5\end{array}$ & $\begin{array}{l}\text { Grade in English } \\
\text { Course last 1/5 }\end{array}$ & $\begin{array}{l}\text { Desired Course of Study } \\
\text { at College }\end{array}$ \\
\hline Jamal & 2.69 & 1 & Biology: A- & $\begin{array}{l}\text { Geometry: B- } \\
\text { Algebra2: C+ }\end{array}$ & $\begin{array}{l}\text { Strategic Writing 1-2: } \\
\text { A+, Advanced } \\
\text { Composition: B+ }\end{array}$ & Psychology, Business \\
\hline Fatou & 3.10 & 1 & $\begin{array}{l}\text { Honor's } \\
\text { World } \\
\text { History: B- }\end{array}$ & Algebra2: C & $\begin{array}{l}\text { American Literary } \\
\text { Traditions: } \\
\text { B }\end{array}$ & $\begin{array}{l}\text { Biology, pre-medicine, } \\
\text { medicine }\end{array}$ \\
\hline Mobali & 2.84 & 0 & Physics :A+ & Geometry: C & $\begin{array}{l}\text { Strategic Writing: 1-2 } \\
\mathrm{B}^{+}\end{array}$ & Human services, business \\
\hline Mutoni & 3.51 & 0 & $\begin{array}{l}\text { Hon World } \\
\text { History: A }\end{array}$ & Algebra2: A- & $\begin{array}{l}\text { Hon American } \\
\text { Literature: } \mathrm{B}^{+}\end{array}$ & $\begin{array}{l}\text { International affairs, } \\
\text { economics }\end{array}$ \\
\hline Nabilah & 3.08 & 1 & $\begin{array}{l}\text { Honor's } \\
\text { World } \\
\text { History: } \\
\text { A+ }\end{array}$ & Algebra2: B & $\begin{array}{l}\text { Honor’s American } \\
\text { Literature: B- }\end{array}$ & $\begin{array}{l}\text { Biology, pre-medicine, } \\
\text { medicine }\end{array}$ \\
\hline Omondi & 3 & 0 & $\begin{array}{l}\text { Physical } \\
\text { Education: } \\
\text { A+ }\end{array}$ & $\begin{array}{l}\text { Pre-Calculus: } \\
\text { B- }\end{array}$ & $\begin{array}{l}\text { Advanced Composition: } \\
\text { A }\end{array}$ & $\begin{array}{l}\text { Engineering, political } \\
\text { science, international } \\
\text { affairs }\end{array}$ \\
\hline
\end{tabular}

\section{Discussion, Implications and Conclusion}

This inquiry indicates that the African refugee youth had effectively adapted to a new society where they learned how to live under the influence of two macro cultures (African and American), and where they purposefully engaged with the social structure of schooling because of its promise for upward social mobility. This inquiry presents evidence of several social phenomena that shaped the refugee youth's relatively successful acculturation and scholastic engagement. The challenging social circumstances and refugee camp conditions in which the African youth and their parents lived were not only constraining, but also a source of resilience training and optimism about a future better life. This inquiry demonstrates how resilience and optimism were valuable assets on which the refugee youth capitalized in their scholastic engagement.

Another influential phenomenon is parenting and schooling in the refugee camps. The refugee parents pushed their children to attend school in the refugee camps and persistently hoped to be resettled in a Western country with better educational opportunities. Despite the curricular and instructional inadequacies in the refugee camp schools, most of these refugee youth were able to acquire foundational literacy skills in their native languages upon which they were able to successfully develop their English literacy skills in the U.S. This confirms the observation in extant literature that literacy skills in the native language can significantly enhance acquisition of literacy skills in the second or foreign languages (Banda, 2003; 
Ndamba, 2008)

With adequate academic English proficiency, the African refugee youth successfully graduated from ELL classes and were mainstreamed into regular classes, some of which were honor's classes. It is evident in this inquiry that the participants and parents arrived in the U.S. without the cultural capital (Bourdieu \& Passeron, 1977) in form of elaborate linguistic codes, verbal facility, general cultural knowledge, and key information about American schooling deemed valuable and necessary for scholastic success (Swartz, 1990). However, this inquiry suggests that the African refugee youth acquired, and that many other African youth with a similar social background can acquire this cultural capital necessary to successfully engage with schooling, and remain academically engaged and complete high school with appropriate post-high school study and career goals.

Upon arrival in the U.S., this inquiry provides evidence that parents soon learned that a selective acculturation model, i.e., one with conscious biculturalism (Waters et al., 2010) would be the best for their children, and therefore carried on their African cultural transmission roles to ensure their children did not totally assimilate to American culture. Also the fact that parents finally settled in a small Northeastern U.S. city without well-established inner city neighborhoods often pervaded by gang activities and subcultures that oppose schooling (Portes, 1995) enhanced the scholastic engagement of the refugee youth. Another important factor was the role played by social networks (Rong \& Brown, 2001, 2002) such as ethnic family networks or associations which helped in fostering biculturalism/bilingualism and providing academic mentoring, community based youth centers which mainly helped the male youth remain focused on schooling, and the multiculturalism advocacy groups which advocated for equity and inclusion.

In this inquiry culture was conceptualized as social structure, i.e., with both enabling and constraining characteristics. African culture evidently equipped all refugee youth with cultural capital (i.e., values of respect, friendliness, acquiescent or agreeable personality traits that were appreciated by American teachers). Also the African cultural notion of filial respect and obedience to adults pushed the refugee youth to obey their parents' will for them to remain in, and complete high school, and plan to move on to college. This notion also enabled the youth to obey other adults in authority (e.g. teachers) for instance by diligently completing all schoolwork as it was assigned it to them. On the other hand, African culture sometimes appeared to be constraining to the youth. Mobali, who prior to resettlement imagined he would see famous people in America, and probably become famous (e.g., through music and sports at which he was good, and from which he believed he could make a good living), had to obey his parents and give up his passion and focus on academics. African culture was constraining especially to the female youth; however, they did not passively obey their culture without criticizing the inherent gender discrimination, which was unfavorably influencing their scholastic engagement.

This inquiry indicates that schooling in the U.S. may be described as a bifurcated social structure in which both opportunities and constraints simultaneously inhere for minority-race immigrants such as African refugee youth. However, to engage these opportunities (such as 
relatively good teachers, free resources such as free homework help and extra academic support, etc.) and at the same time transcend the inherent countervailing forces (such as racial prejudice and discrimination), agency, i.e., the intentional capacity of an actor/agent to meaningfully act upon social circumstances in the world (Ratner, 2000), is needed. It is evident in this inquiry that the African refugee youth displayed various levels of what I conceptualize in this inquiry as agentic scholastic engagement (ASE). I define the emergent concept of ASE as the purposeful academically oriented actions of at-risk students that seek to take advantage of available opportunities while counteracting constraining forces that are inherent in American schooling.

ASE as conceptualized in this inquiry is not a monolithic student characteristic; rather it is a malleable phenomenon that is shaped by various influences. The African cultural value of filial respect and obligation, for instance, were a relevant phenomenon to the AES concept not only because of its promise for cultural capital, but also for its agentic value. A few participants opportunistically interpreted the African cultural value of filial respect and obligation by acting in ways deemed antithetical to this value, i.e., by protesting against inequitable instructional practices and perceived racism. While certain African parents might have viewed this disaffected African student behavior as antithetical to the ideal of deference to school authority, some minority-culture students whose academic engagement was at stake viewed it differently. They interpreted it as their effort to influence school conditions so they could better be positioned to obey their parents' wish, and fulfill their own desire to succeed at school. Furthermore, by protesting against perceived racism, these participants were using their acquired American cultural knowledge that citizens could freely assert their right to fair treatment in the light of the American cultural ideals of diversity, equality, and justice (Adams, 1988; Hollins, 1996 as cited in Sheets, 2005). These actions of a few African refugee youth were agentic in that they sought to transform the structure/culture of schooling, thereby enhancing their scholastic engagement. This agentic feat is akin to what Hayes (1994) termed as "structurally transformative agency" (p. 64). This inquiry provides evidence that some participants' agentic actions contributed to the emergence at OCHS and in the school district of what Mugisha (2013) conceptualized as culturally responsive instructional leadership, i.e., “Those purposeful, well-intentioned, creative, and collaborative actions that a principal takes to enhance the academic engagement and achievement of minority-culture students” (p. 15).

On the other hand, this research also recognizes that many at-risk students in the U.S. find themselves using their agency to subvert social structures (e.g., schooling) in non-transformative ways, for instance by disengaging from the social structure of schooling (Willis, 1977), which is akin to Haye's (1994) concept of "structurally reproductive agency" (p. 63). This kind of agentic behavior, which I argue was romanticized by Willis, is a slippery slope that may lead the at-risk students into a cycle of undesirable social circumstances that are antithetical to the dreams of both the African refugee youth and their parents. This inquiry therefore underscores the importance of the ASE concept in the schooling experiences of African refugees. I acknowledge the limitation that the ASE concept emerged from a narrow purposeful sample of African refugee youth and therefore cannot be generally applied to the study of all refugee or immigrant high school youth in the US. However, the ASE concept 
can inform further research on the schooling experiences of refugee youth from other minority cultural and racial groups in America. I recommend specifically participatory action research to not only further develop the ASE concept, but also to empower marginalized racial minority youths and families to participate in scholastic transformative interventions as a strategy of enhancing academic engagement of refugee students at-risk of scholastic failure.

This research also bears important implications for instructional practitioners. American schools that enroll refugee students from Africa should not assume that refugee children were all equally intellectually disadvantaged by the conditions in the refugee camps. In this inquiry it is evident that some schools in the refugee camps had better support from aid and humanitarian agencies, and some participants had educated refugee parents, which enabled some refugee children to develop good literacy foundations. In this regard, American schools will need to have mechanisms in place for assessing these foundations and better planning appropriate instructional interventions for different refugee students. This inquiry also demonstrates that African students and their parents are generally optimistic about American schooling because of its potential for upward mobility. Therefore, American public schools with positive school cultures and climates that counter deficit thinking (Roxas \& Roy, 2012; Roy \& Roxas, 2011) about African refugee youth and their families, and which adopt culturally responsive instructional leadership strategies (Mugisha, 2013) are better positioned to serve refugee youth from minority racial groups.

\section{References}

Adam, D. W. (1998). Fundamental considerations: The deep meaning of Native American schooling, 1880-1900. Harvard Educational Review, 58(1), 1-28.

Banda, F. (2003). A survey of literacy practices in black and colored communities in South Africa: Towards a pedagogy of multiliteracies. Language, Culture and Curriculum, 16(2), 106-129. http://dx.doi.org/10.1080/07908310308666661

Bellah, R. N. (1998). Is there a common American culture? The Journal for the American Academy of Religion, 66(3), 613-625. http://dx.doi.org/10.1093/jaarel/66.3.613

Bellah, R. N., Madsen, R., Sullivan, W. M., Swindler, A., \& Tipton, S., M. (1986). Habits of the heart: Individualism and commitment in American life. New York, NY: Harper \& Row Publishers.

Berry, J. W., Poortinga, Y. H., Segall, M. H., \& Dasan, P. R. (2002). Cross-cultural psychology: Research and applications ( $2^{\text {nd }}$ ed.). Cambridge, UK: Cambridge University Press.

Bigelow, M. (2009). Somali adolescents' negotiation of religious and racial bias in and out of $\begin{array}{llll}\text { school. Theory into } & \text { 27-34. }\end{array}$ http://dx.doi.org/10.1080/00405840701764706

Blakely, M. M. (1983). Southeast Asian refugee parents: An inquiry into home-school 
communication and understanding. Anthropology and Education Quarterly, 14(1), 43-68. http://dx.doi.org/10.1525/aeq.1983.14.1.05x1181k

Bourdieu, P. (1986). The forms of capital. Handbook of theory and research for the sociology of education. New York, NY: Greenwood.

Bourdieu, P. (1998). Practical reason. Stanford, CA: Stanford University Press.

Bourdieu, P., \& Passeron, J. (1977). Reproduction in education, society and culture. London, UK: Sage.

Chapman, E. (2003). Alternative approaches to assessing student engagement rates. Practical Assessment, Research \& Evaluation, 8(13), 1-11.

Chavez, C. (2008). Conceptualizing from the inside: Advantages, complications, and demands on insider positionality. The Qualitative Report, 13(3), 474-494.

Chhuon, V., \& Hudley, C. (2010). Asian American Ethnic options: How Cambodian students negotiate ethnic identities in a U.S. urban school. Anthropology and Education Quarterly, 41(4), 341-359. http://dx.doi.org/10.1111/j.1548-1492.2010.01096.x

Coffey, A., \& Atkinson, P. (1996). Making sense of qualitative data: Complementary research strategies. Thousand Oaks, CA: SAGE.

Creswell, J. W. (2007). Qualitative inquiry \& research design: choosing among five approaches ( $2^{\text {nd }}$ ed.). Thousand Oaks, CA: Sage Publications.

DeCapua, A., Smathers, W., \& Tang, L. (2007). Schooling interrupted. Educational Leadership, 64(6), 40-46.

Denzin, N. K., \& Lincoln, Y. S. (2000). Handbook of qualitative research ( $2^{\text {nd }}$ ed.). Thousand Oaks, Calif.: Sage Publications.

Dwyer, S. C., \& Buckle, J. L. (2009). The space between: On being an insider-outsider inqualitative researcher. International Journal of Qualitative Methods, 8(1), 54-63.

Fordham, S., \& Ogbu, J. (1986). Black students' school success: Coping with the burden of 'acting white'. Urban Review, 18, 176-206. http://dx.doi.org/10.1007/BF01112192

Fredricks, J. A., Blumenfeld, P. C., \& Paris, A. H. (2004). School engagement: potential of the concept, state of the evidence. Review of Educational Research, 74(1), 54-109. http://dx.doi.org/10.3102/00346543074001059

Giddens, A., Duneier, M., \& Appelbaum, P. R. (2003). Introduction to Sociology (4 ${ }^{\text {th }}$ ed.). New York, NY: W.W. Norton \& Company.

Gone, J. P., \& Alcántara, C. (2010). The ethnographically contextualized case study method: Exploring ambitious achievement in an American Indian Community. Cultural Diversity and Ethnic Minority Psychology, 16(2), 159-168. http://dx.doi.org/10.1037/a0013873

Hayes, S. (1994). Structure and agency and the sticky problem of culture. Sociological 
Theory, 12(1), 57-72. http://dx.doi.org/10.2307/202035

Heine, S. (2011). Cultural psychology. San Francisco, CA: W. W. Norton \& Co.

Hollins, E. (1996). Culture in school learning: Revealing the deep meaning. Mahwah, NJ: Lawrence Erlbaum Associates.

Hones, D. F. (2002). American dreams, global visions: Dialogic teacher research with refugee and immigrant families. Mahwah, NJ: Lawrence Erlbaum Associates.

Kamya, H. A. (1997). African immigrants in the United States: The challenge for research and practice. Social Work, 42(2), 154-165. http://dx.doi.org/10.1093/sw/42.2.154

Kirova, A. (2001). Loneliness in immigrant children: Implications for classroom practice. Childhood $\quad$ 260-267. http://dx.doi.org/10.1080/00094056.2001.10521648

Kruizenga, T. M. (2010). Teaching Somali children: What perceived challenges do Somali students face in the public school system. International Journal of Education, 1(1), 1-17.

Lassiter, J., E. (2000). African culture and personality: Bad science, effective social activism, or a call to reinvent ethnology? African Studies Quarterly, The Online Journal for African Studies, 3(3), 1-21.

Lee, J., \& Shute, V. (2009). The influence of noncognitive domains on academic achievement in $K-12$. Princeton, NJ: Educational Testing Service (ETS).

Lee, S. (2001). More than "model minorities" or “delinquents": A look at Hmong American high school students. Harvard Educational Review, 71(3), 505-528.

Lee, S. (2002). Learning “America”: Hmong American high school students. Education and Urban Society, 34(34), 233-246. http://dx.doi.org/10.1177/0013124502342007

Marshall, C., \& Rossman, B. G. (2011). Designing qualitative research. Los Angeles, CA: SAGE.

Martin, D. C., \& Yankay, J. E. (2012). Refugees and Asylees: 2012. Washington, DC: Department of Homeland Security-Office of Immigration Statistics. Retrieved from http://www.dhs.gov/sites/default/files/publications/ois_rfa_fr_2012.pdf

McBrien, J. L. (2003). A second chance for refugee students. Educational Leadership, 61(2), 76-79.

McBrien, J. L. (2005). Educational needs and barriers for the refugee students in the United States: A review of the literature. Review of Educational Research, 75(3), 329-364. http://dx.doi.org/10.3102/00346543075003329

Merriam, S. B. (1998). Qualitative research and case study applications in education. San Francisco, CA: Jossey-Bass.

Mugisha, M., V. (2013). Culturally responsive instructional leadership: A conceptual 
exploration with principals of three New Zealand mainstream schools. International Journal of Multicultural Education, 15(2), 1-20.

Ndamba, G. T. (2008). Mother tongue usage in learning: An examination of language preferences in Zimbabwe. The Journal of Pan African Studies, 2(4), 172-188.

Ogbu, J. U. (1982). Cultural discontinuities and schooling. Anthropology and Education Quarterly, 13(4), 290-307. http://dx.doi.org/10.1525/aeq.1982.13.4.05x1505w

Ogbu, J. U. (1987). Variability in minority school performance: A problem in search of an explanation. Anthropology and Education Quarterly, 18, 312-334. http://dx.doi.org/10.1525/aeq.1987.18.4.04x0022v

Office of Immigration Statistics (OIS). (2012). 2012 yearbook of immigration statistics. Washington, DC: Department of Homeland of Security-Office of Immigration Statistics. Retrieved from https://http://www.dhs.gov/yearbook-immigration-statistics-2012-refugees-and-asylees

Patton, M. Q. (2002). Qualitative research \& evaluation methods ( $3^{\text {rd }}$ ed.). Thousand Oaks, CA: Sage Publications.

Portes, A. (1995). Segmented assimilation among new immigrant youth: A conceptual framework. In R. G. Rumbault \& W. A. Cornelius (Eds.), California's Immigrant Children (pp. 71-76). San Diego, CA: Center for U.S.-Mexican Studies.

Portes, A., \& Rumbaut, R. G. (2001). Legacies: The story of the immigrant and second generation. Berkeley, CA: University of California Press.

Pryor, C. B. (2001). New immigrants and refugees in American schools: Multiple voices. $\begin{array}{lll}\text { Childhood 275-283. } & \text { 77(5), }\end{array}$ http://dx.doi.org/10.1080/00094056.2001.10521650

Ratner, C. (2000). Agency and culture. Journal for the Theory of Social Behavior, 30(4), 413-434. http://dx.doi.org/10.1111/1468-5914.00138

Rong, X. L., \& Brown, F. (2001). The effects of immigrant generation and ethnicity on educational attainment among young African and Caribbean Blacks in the United States. Harvard Educational Review, 71(3), 536-565.

Rong, X. L., \& Brown, F. (2002). Socialization, culture, and identities of black immigrant children. Education and Urban Society, 34(2), 247-273.

Rong, X. L., \& Preissle, J. (1998). Educating immigrant students: What we need to know to meet the challenge. Thousand Oaks, CA: Corwin Press.

Roxas, K., \& Roy, L. (2012). "That's how we roll": A case study of a recently arrived refugee student in an urban high school. Urban Review, 44(1), 468-486. http://dx.doi.org/10.1007/s11256-012-0203-8

Roy, L., \& Roxas, K., C. (2011). Whose deficit is this anyhow? Exploring counter-stories of 
Somali Bantu refugees' experiences in "doing school". Harvard Educational Review, 81(3), 521-541.

Rubinstein. (2001). Culture, structure and agency: Toward a truly multidimensional society. Thousand Oaks, CA: Sage Publication.

Sheets, H. R. (2005). Diversity pedagogy: Examining the role of culture in the teaching-learning process. New York, NY: Pearson.

Singer, A., \& Wilson, J. H. (2006). From 'There' to 'Here': Refugee resettlement in metropolitan America. Washington, DC: The Brookings Institution.

Swartz, D. (1990). Pierre Bourdieu: Culture, education, and social inequality. In K. J. H. Doughtery (Ed.), Education and Society: A Reader (pp. 70 -80). Orlando, FL: Harcourt, Brace, Jovanovich.

Tatum, D. B. (1997). “Why are all the black kids sitting together in the cafeteria?”. New York, NY: Basic Books.

Trueba, H., Jacobs, L., \& Kirton, E. (1990). Cultural conflict and adaptation: The case of Hmong children in American society. New York, NY: Falmer Press.

Waters, M. C., Tran, V. C., Kasinitz, P., \& Mollenkopf, J. H. (2010). Segmented assimilation revisited: Types of acculturation and socio-economic mobility in young adulthood.

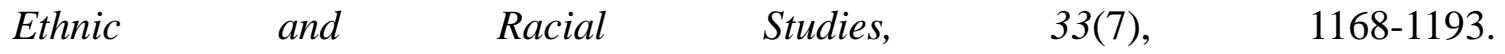
http://dx.doi.org/10.1080/01419871003624076

Willis, P. E. (1977). Learning to labour: How working class kids get working class jobs $\left(1^{\text {st }}\right.$ ed.). Westmead, England: Saxon House.

Zhou, M. (2001). Straddling different worlds: The acculturation of Vietnamese refugee children. In R. G. Rumbaut \& A. Portes (Eds.), Ethnicities: Children of immigrants in America. Berkeley, CA: University of California Press.

\section{Copyright Disclaimer}

Copyright for this article is retained by the author(s), with first publication rights granted to the journal.

This is an open-access article distributed under the terms and conditions of the Creative Commons Attribution license (http://creativecommons.org/licenses/by/3.0/). 